\title{
EMPOWERMENT TRAINING IMPACT OF PORNOGRAPHY THROUGH INTERNET IN KELURAHAN MAPHAR, JAKARTA BARAT
}

\author{
Inge Hutagalung \\ Universitas Mercu Buana, Indonesia \\ inge_hutagalung@yahoo.com
}

\begin{abstract}
Pornography causes damage to the five parts of the brain, especially in the pre frontal cortex (the right part of the brain behind the forehead of logic brain). Consequently the part of the brain responsible for logic will be deformed due to unfiltered hyper stimulation (the brain only seeks pleasure without consequence). In addition, the most worrying impact is a decrease in academic achievement and learning ability, as well as a reduced decision-making ability. Furthermore, an increasing number of active sexually active adolescents will also increase the case of unwanted pregnancies, and abortion actions that are often regarded as a solution to the problem. Through community development activities are expected to be able to contribute in the form of data and information related to the level of pornography addiction that is rife among teenagers. From the understanding that is formed, it is hoped that it can become a material consideration for policy making related to the prevention and handling of pornography among teenagers in Indonesia.
\end{abstract}

Keywords: Active sexually, pornography, unwanted pregnancies

\section{INTRODUCTION}

The extraordinary development in the field of information and communication media technology that is so sophisticated has an impact on the information explosion that the media continues to bring to one's personal life. Information seems to flow without knowing time through various types of media, such as newspapers, tabloids, magazines, books, comics, radio, television, film, video, VCD / DVD, internet and mobile phones (HP). All of them "surrounded and competed" filled the individual's spare time, mixed with thousands, millions and even billions of factual, real, and truly important and trustworthy information.

One of the social problems in Indonesia that needs attention regarding the abundance of information is pornography. Pornography is like an octopus whose tentacles twist all over. Ranging from feature films, television, comics, novels, newspapers, tabloids, magazines, VCDs / DVDs, cellphones, as well as internet sites, pornography shows that are directly or indirectly easy to find, both in big and small cities, even to rural though.

From Google Trends data, it is known that in 2015 Indonesia was ranked as the top accessing keyword for 'sex' and 'phone' on internet search engines (kompasiana.com, 25 June 2015) of particular concern, when examined more deeply it turned out that access to the largest pornographic material was teenagers.

The above facts are interesting because actually pornography is forbidden in Indonesia, and the prohibition has been regulated in the Pornography Law No. 44 of 2008. The question that then arises in the context of pornographic information is if pornography is forbidden why do teenagers actively make choices on pornographic information.

Sarwono (2007), Euis (2009), Hutagalung (2012, 2016) shows that the reason teenagers actively make choices on pornographic information is because teenagers need information about the changes that occur in themselves and the implications for sexual behavior in order to foster a sense of responsibility and health awareness. The more capable parents provide sexual information to children, the lower the search behavior for pornographic information, and vice versa. Ironically, the provision of 
sexual information for adolescents is still a matter of constant debate. The first argument is that conversations about the topic of sex are considered taboo or unusual to be discussed in national culture, because sex is a matter that is too personal or considered a matter of "in a blanket". There is an assumption that if adolescents get information about sex, especially the issue of reproductive health services, it will actually encourage teenagers to engage in sexual activity and promiscuity earlier. Talking about sexuality issues to adolescents, as well as fishing teenagers to do trial and error, sexuality information is still considered a form of pornography.

While the second opinion states, teenagers need sexual information. Giving sexual information in general is a process of educating that is cognitive in nature, which has a broad impact on conative and one's behavior. Giving sexual information in general is a process of educating that is cognitive in nature, which has a broad impact on conative and one's behavior.

Concerns arise along with the effects that pornography has on users and the effects they have on people who are loved by the user. Pornography has serious negative side effects. Pornography causes damage to five parts of the brain, especially in the pre frontal cortex (the part of the brain that is right behind the forehead and the brain of logic). As a result, the part of the brain responsible for logic will experience a defect due to unfiltered hyper stimulation (the brain only seeks pleasure without consequences). Damage to the brain will result in victims becoming easily bored, feeling alone, angry, depressed and tired. In addition, the most worrying impact was a decrease in academic achievement and learning ability, as well as a reduced decision-making ability (quoted from the Pornography Danger seminar, September 2015).

Pornography also impacts on the approach of teenagers in "permissive" lives, in matters of sex. Events in shows or readings motivate and stimulate teenagers in Indonesia to emulate or practice things seen or read, without thinking of cultural differences, values and norms in the community.

Furthermore, the increasing number of adolescents who have active sexual behavior, will also increase cases of unwanted pregnancy (KTD), and abortion actions that are often regarded as a solution to the problem of KTD. The act of abortion is very high risk for reproductive health. Complications experienced from abortion can cause severe bleeding, infection and poisoning from materials used for abortion, cervical cancer, damage to the genitals and permanent damage to the reproductive organs that can further lead to infertility or even death (Soetjiningsih, 2006; Damayanti, 2007).

\section{METHOD}

\section{Activity Objectives}

This activity has several objectives, among other to conduct mapping of the problems that are behind the search for pornographic information among teenagers, knowing the level of pornography addiction among teenagers, educate brain damage from pornography among teenagers, and socialization of curative and preventive actions against pornography addiction among teenagers.

\section{Flow Chart Explanation}

The socialization of prevention and prevention of pornography addiction among teenagers was carried out in the form of pornography addiction literacy and assessment, consisting of 4 stages with details of the process stages as follows:

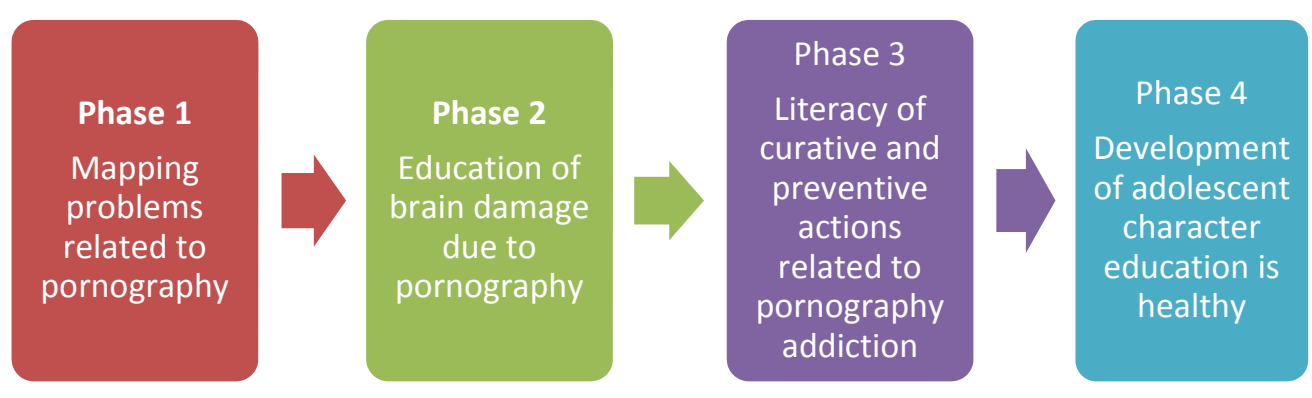


Phase 1 is a mapping of problems related to pornography, which consists of stages of social mapping activities related to pornography, determining the location of activities, drafting concepts and instruments, forming a team to plunge into the field.

Phase 2 is the socialization and education of brain damage due to pornography. At this stage it is explained what is the meaning of addiction, the level of pornography addiction, brain damage that occurs due to pornography addiction. After educating brain damage, individual assessments were conducted regarding the level of pornography addiction to the participants.

Phase 3 is a literacy of curative and preventive actions related to pornography addiction. At this stage, what curative and preventive actions should be explained should be done so that individuals understand and can anticipate addiction to pornography.

Phase 4 is a socialization of the development of youth character in healthy behavior. This activity is carried out to remember to adolescents that healthy living behavior will help teens from being addicted to pornography.

Dissemination of prevention and prevention of pornography addiction among teenagers using Learning Methodology is a learning approach method that focuses on participant participation based on experience, stimuli and participant responses to these stimuli. That the success of the implementation will only be achieved if the participants have the sincerity to understand and change to be better in everything, especially in overcoming pornography addiction. For this purpose socialization is presented through: knowledge aspects, with classical; and attitude aspects, with group discussion.

\section{Target Audience}

Dissemination of prevention and prevention of pornography addiction among teenagers was carried out in two locations. Namely, RPTRA Matahari, Maphar Village, Taman Sari Subdistrict, West Jakarta and SMAN 17 with 4 weeks of service time, from October 9, 2017 to October 31, 2017.

\section{Realization of Activities}

Phase 1 is a social mapping that has been carried out in two stages of work with the following descriptions:

- Social mapping related to pornography and location of activities carried out: on October 9, 2017 at RPTRA Matahari, Kelurahan Maphar, Kecamatan Taman Sari, West Jakarta.

- Formulation of concepts and instruments and team formation to plunge the field are carried out: on 11-13 October 2017 at the Faculty of Psychology, Mercu Buana University, Meruya Campus, West Jakarta.

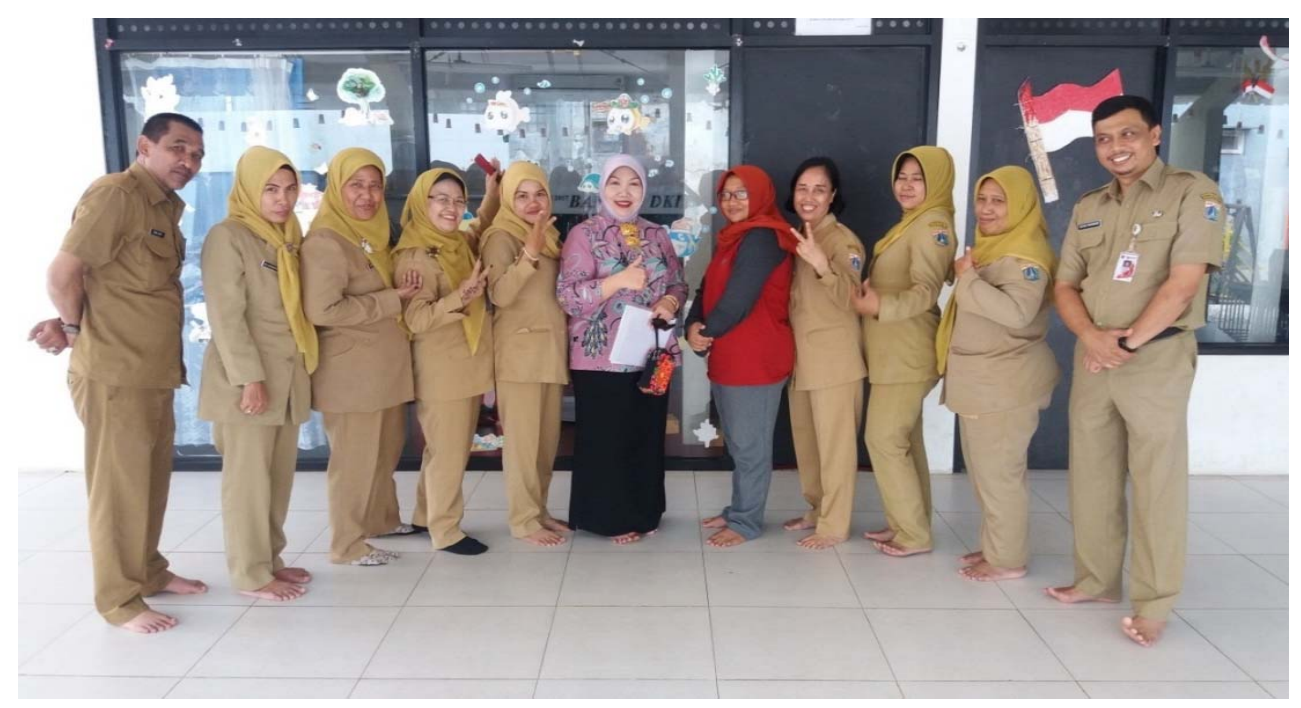

Figure 1. Social mapping related to pornography and determination of location of activities at RPTRA Matahari 
Phase 2 was the socialization and education of brain damage due to pornography carried out on October 31, 2017 at SMAN 17 followed by 28 participants.

Phase 3 is a literacy of curative and preventive actions related to pornography addiction. At this stage, what curative and preventive actions should be explained should be done so that individuals understand and can anticipate addiction to pornography. This activity was carried out at SMAN 17 on October 31, 2017.

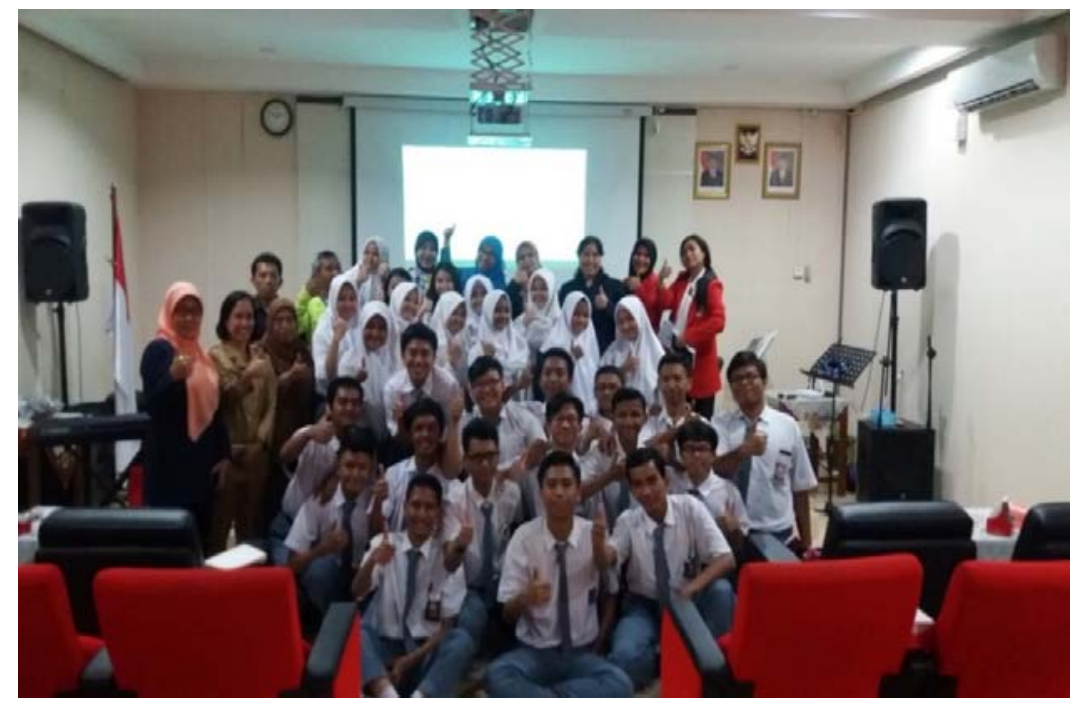

Figure 2. Socialization and education of brain damage due to pornography in the Hall of SMAN 17

Phase 4 is a socialization of the development of youth character in healthy behavior. This activity is carried out to remember to adolescents that healthy living behavior will help teens from being addicted to pornography. This activity was carried out on October 14, 2017 at RPTRA Matahari, Maphar Village, Taman sari District, West Jakarta.

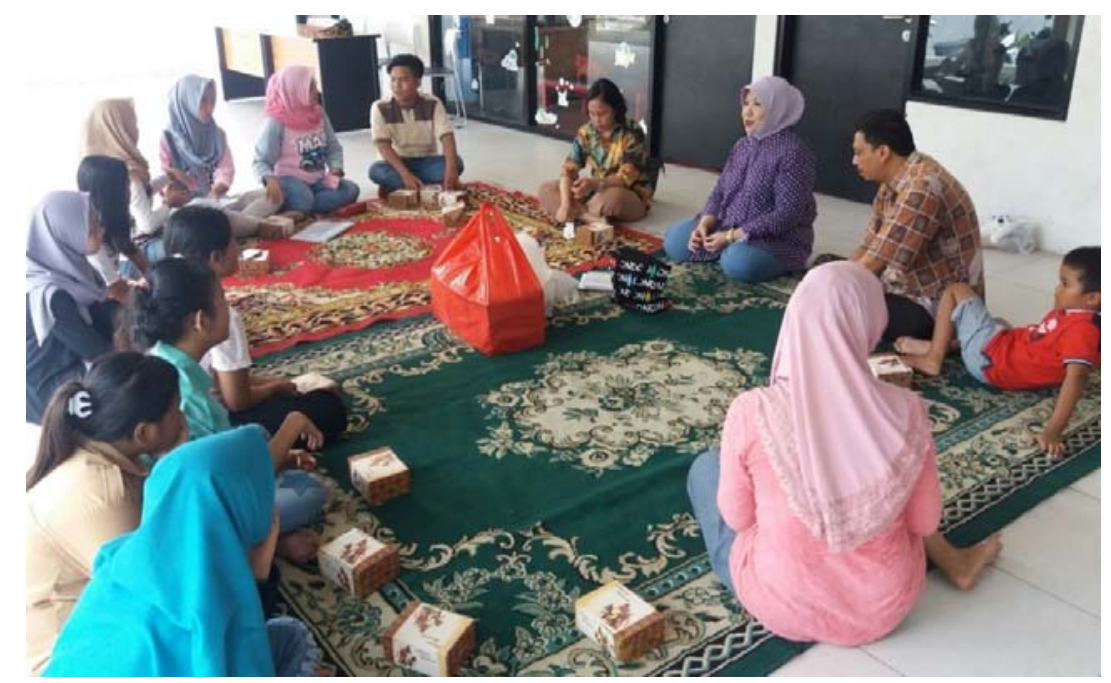

Figure 3. The socialization of the development of adolescent characters behaves healthily at RPTRA Matahari 


\section{CONCLUSION}

Overall, the socialization participants were dominated by individuals who had personalities with the type of Friend. Participants are able to express their ideas and opinions well. The thinking patterns of the participants are quite open and flexible. The socialization atmosphere is quite lively and 'live'. The participants are creative, honest and tend to be brave to express their opinions openly, both in group discussions and individually. The participants stated that the socialization activities were interesting, many things were 'newly' obtained and learned during the activity. The socialization material is very useful in 'delivering' participants to better understand the effects and ways of dealing with pornography addiction.

From the assessment results it is known that the level of pornography addiction from female participants is at the level of recreation (score 0-25). That is, looking for pornographic information for entertainment. Female participants numbered 12 people aged 15-17 years. From the assessment results of male participants (male participants numbered 16 people aged 15-18 years) it is known that the level of pornography addiction from male participants is at a dangerous and risky level (score 26-49). That is, looking for pornographic information as a necessity. Furthermore, there are four (4) children who are at the level of addiction (score 50 and above).

\section{Recommendations}

The duration of the activity can be considered to be extended, to three months. It is recommended to remember that collecting participants needs time to coordinate, to obtain accurate addiction data requires individual approach time, and the socialization of combating pornography addiction requires an individualized approach according to the level of addiction, which is carried out intensively.

\section{REFERENCES}

Damayanti, R. (2007). Peran Biopsikososial Terhadap Perilaku Berisiko Tertular HIV Pada Remaja SLTA Di DKI Jakarta, Disertation FKM UI.

Euis Supriati dan Sandra Fikawati. 2009. Efek Paparan Pornografi Pada Remaja SMP Negeri Kota Pontianak Tahun 2008. Makara, Sosial Humaniora, Vol. 13, No. 1, Juli 2009: 48-56.

Hutagalung, Inge. (2012). Analisis Faktor Penyebab Selective Exposure. Disertation Universitas Indonesia.

. (2016). Disonansi Kognitif Pada Perilaku Seks Pranikah, Jurnal Komunikasi Ikatan sarjana Komunikasi Indonesia, Vol.1 No.2.

Soetjiningsih. (2006). Remaja Usia 15-18 Tahun Banyak Lakukan Perilaku SeksualPranikah.http://www.ugm.ac.id/index.php?page=rilis\&artikel=1659.diakses tanggal 13 Juli 2010. 